\title{
APPLICATION OF DIFFERENT FERTILIZERS IN SUBSTRATE FOR Kalanchoe luciae Raym.-Hamet CULTIVATION
}

\author{
Aplicação de diferentes fertilizantes em substrato de cultivo de Kalanchoe luciae Raym.-Hamet
}

\author{
Marília Andrade Lessa ${ }^{1}$, Patrícia Duarte de Oliveira Paiva ${ }^{2}$, Camila Magalhães Lameiras Alves ${ }^{3}$, Maria Leandra Resende ${ }^{4}$
}

\begin{abstract}
Succulents present great commercial importance, but information on the cultivation of these plants are not enough, especially considering the use of fertilizers during the growth phase. The objective of this study was to evaluate the effect of different fertilizers applied to the substrate in the cultivation of Kalanchoe luciae Raym.-Hamet. Cuttings measuring $6 \mathrm{~cm}$ in height and $12 \mathrm{~cm}$ in diameter were cultivated in $1.5 \mathrm{~L}$ pots containing the substrate ( 1 soil: 1 sand: 1 vermiculite). In this experiment, the effect of the fertilization based on NPK 10:10:10 was evaluated with and without the addition of a fertilizer mixture composed of $5 \mathrm{~g}$ bone flour, $5 \mathrm{~g}$ dolomite limestone, and $50 \mathrm{~g}$ ground charcoal, this proportion that was used for each $1.5 \mathrm{~L}$ substrate. After 60 days, an increase in the number of leaves, which was proportional to the increase in the doses of NPK applied, was verified. Even though the plants presented higher number of leaves (18.34) and higher height $(18.73 \mathrm{~cm})$ for the substrate with $1.5 \mathrm{~g} \mathrm{~L}^{-1}$ of NPK 10:10:10, plants did not reach the compact aspect suggested by some producers. The addition of fertilizer mixture presented no effect on the leaves number and neither to the plant height, however, it was observed that the plants that received the fertilizer mixture presented the fifth leaf with bigger diameter. None of the treatments favored the formation of one of the most important characteristics of this species, the reddish color on the borders of the leaves.
\end{abstract}

Index terms: Crassulaceae, fertilization, ornamental plants.

\section{RESUMO}

As suculentas apresentam grande importância comercial, mas, as informações sobre o cultivo destas plantas ainda são escassas, especialmente em relação à fertilização durante a fase de crescimento. Neste trabalho, objetivou-se avaliar o efeito de diferentes adubações no substrato para cultivo de Kalanchoe luciae Raym.- Hamet. Mudas com $6 \mathrm{~cm}$ de altura e $12 \mathrm{~cm}$ de diâmetro foram cultivadas em vasos de 1,5 L, contendo o substrato (1 terra: 1 areia: 1 vermiculita). Avaliou-se, nesse experimento, o efeito de adubações à base de NPK 10:10:10, com e sem adição de uma mistura de adubos composta de $5 \mathrm{~g}$ de farinha de osso, $5 \mathrm{~g}$ de calcário dolomítico e $50 \mathrm{~g}$ de carvão vegetal triturado, proporção essa, utilizada para cada 1,5 L de substrato. Após 60 dias, verificou-se que o aumento do número de folhas foi proporcional ao aumento das doses de NPK aplicadas. Apesar de apresentarem maior número de folhas $(18,34)$ e maior altura das plantas $(18,73 \mathrm{~cm})$ para o substrato com 1,5 $\mathrm{g} \mathrm{L}^{-1}$ de NPK 10:10:10 as plantas não atingiram o aspecto compacto sugerido por alguns produtores. Não houve efeito da adição da aplicação da mistura de adubos sobre o número de folhas formadas e altura da planta, entretanto, observou-se que as plantas que receberam a mistura de adubos apresentaram maior diâmetro da $5^{\text {a }}$ folha. Nenhum dos tratamentos favoreceu a formação de uma das características mais importantes desta espécie, a de apresentar suas bordas avermelhadas.

Termos para indexação: Crassulaceae, fertilização, plantas ornamentais.

(Received in june 6, 2006 and approved in july 9, 2008)

\section{INTRODUCTION}

Plants of the family Crassulaceae occur worldwide but the majority of the taxa are restricted to subtropical and temperate regions of the Northern Hemisphere and South Africa, frequently in arid habitats (Oldfield, 1997; Judd, 2002).

In their natural habitat, cacti and succulents are able to absorbing all kinds of minerals present in the soil. As result of the sporadic and non-balanced availability of minerals, several cacti and succulents can only survive on their natural habitat. However, they can bloom when cultivated with regular fertilization (Hewitt, 1997).

It is fundamental to have knowledge of the basic necessities for the culture of succulents in order to provide the ideal basic conditions to the plants for their development outside their natural conditions (Almeida et al., 2008). Basic necessities include fertilization, substrate composition, irrigation interval and light, among others.

\footnotetext{
'Biologist, Doctorate student of Agricultural Department /DAG - Federal University of Lavras/UFLA - Cx. P. 3037 - $37200-000$ - Lavras, MG marilialessa@terra.com.br

${ }^{2}$ Agronomist, Ph.D., Professor of Agricultural Department/DAG - Federal University of Lavras/UFLA - Cx. P. 3037 - $37200-000$ - Lavras, MG pdolivei@ufla.br. CNPq grantee

${ }^{3}$ Agronomist - Federal University of Lavras/UFLA - Cx. P. 3037 - 37200-000 - Lavras, MG - cacalameiras@hotmail.com

${ }^{4}$ Agronomist, Doctorate student of Agricultural Department/DAG - Federal University of Lavras/UFLA - Cx. P. 3037 - $37200-000$ - Lavras, MG mleandrar@yahoo.com.br
} 
One of the substrate functions is to provide nutrients to the plant (Malavolta, 1980). However, the substrate does not always contain nutrients in satisfactory concentrations and it is necessary to add the nutrients through fertilizer formulations at specific concentrations for each type of culture.

Cacti and succulents are plants that need regular fertilization during the growth phase, with a balanced quantity of minerals, which include mainly nitrogen, phosphorus and potassium (Hewitt, 1997).

According to Olmos (1978), cacti and succulents respond well to fertilization with liquid fertilizers, composed of $15 \%$ nitrogen, $20 \%$ phosphorus, and $30 \%$ potassium. As stated by Bell (2001), there are commercial fertilizers specifically formulated for the culture of cacti and succulents, as the formulation NPK 8-34-32. Still, according to the same author, the NPK formulations rich in potassium such as 15-15-30 or other formulations recommended for tomato culture like NPK 10-10-25 and 11-9-30 can also be used. Nevertheless, such formulations are rarely found in the Brazilian market.

Upon studying the fertilization of cacti with ammonium nitrate and potassium sulphate, monthly applied on different substrate, Seixas (2001) observed that the fertilization promoted higher percentage of emergence of plantlets, as well as higher number of plantlets that survived, which also presented higher height.

However, no information on fertilization of the culture of Kalanchoe luciae Raym.-Hamet was found. Thus, the objective of this research was to evaluate the effect of different fertilizers on the development of cuttings of this species.

\section{MATERIALAND METHODS}

The experiment was carried out from December 2004 to March 2005, with a total of 90 days. The average maximum and minimum temperature in the period were $44^{\circ} \mathrm{C}$ and $16^{\circ} \mathrm{C}$, respectively, and the relative humidity was $71.6 \%$.

Cuttings of the species Kalanchoe luciae Raym.-Hamet (6 cm tall and $12 \mathrm{~cm}$ diameter) acquired from succulent producer and collector were used as plant material for the experiment. The cuttings were individually planted in pots containing $1.5 \mathrm{~L}$ substrate.

In this experiment, the effect of application of fertilizers based on NPK was evaluated, in the proportion of 10:10:10, with and without the addition of a mixture of fertilizers, which was added to a basic substrate constituted of dark-red latosol (LVE) (dystrophic and clayish texture), sand, and vermiculite, in the proportion of $1: 1: 1$. The mixture of fertilizers was composed of $5 \mathrm{~g}$ bone flour, $5 \mathrm{~g}$ dolomitic limestone, and $50 \mathrm{~g}$ ground charcoal, according to the recommendation by Lessa et al. (2004). When added, this quantity was used for each $1.5 \mathrm{~L}$ substrate.

The treatments were constituted by: T1 - control; T2 - 0 NPK + mixture; T3 - 0.5 g NPK; T4 - 0.5 g NPK + mixture; T5 - $1.0 \mathrm{~g}$ NPK; T6 - $1.0 \mathrm{~g}$ NPK + mixture; T7 - 1.5 g NPK; T8 - 1.5 g NPK + mixture.

The experiment was carried out under $50 \%$ shade net (Sombrite ${ }^{\hat{a}}$ ) and the irrigations were done manually every three days. The experimental design used was the randomized block experiment, with split plot in time, being factorial in the plots and time in the subplots, with eight treatments, each one containing four replications, with two plants per plot, in a total of eight plants per treatment.

The evaluations were performed on two occasions: the first at 60 days after the installation of the experiment and the second at the 90th day when the plants already presented an adequate size for commercialization. In both evaluations the number of leaves, plant height, plant diameter, and the diameter of the fifth leaf were assessed. The dry mass weight of leaves and roots was evaluated only at 90 days and the leaf analysis was performed only at this occasion as well. The plant diameter was obtained by having as standard measurement, the extremities of the biggest pair of leaves formed in the plant.

The results observed were submitted to analysis of variance, with the assistance of the SISVAR ${ }^{\circledR}$ program (FERREIRA, 2000). Tukey test at 5\% probability was used to compare the means between the treatments.

The mathematical model used for the analysis of these experiments was:

$$
\mathrm{Y}_{\mathrm{ijkl}}=\mu+\mathrm{A}_{\mathrm{i}}+\mathrm{M}_{\mathrm{j}}+\mathrm{AM}_{\mathrm{ij}}+\beta_{\mathrm{k}}+\varepsilon_{(\mathrm{ijk})}+\tau_{1}+\varepsilon_{(\mathrm{kl})}+\mathrm{A} \tau_{\mathrm{il}}+\mathrm{M} \tau_{\mathrm{jl}}+\mathrm{AM} \tau_{\mathrm{ijl}}+\varepsilon_{(\mathrm{ijkl})}
$$


Where:

$\mathrm{Y}_{\mathrm{ijkl}}=$ experimental observation that received the $\mathrm{i}^{\text {th }}$ dose of NPK, $\mathrm{j}^{\text {th }}$ mixture, $\mathrm{k}^{\text {th }}$ block and $\mathrm{l}^{\text {th }}$ time; $\mu=$ overall mean

$A_{i}=$ effect of the $i^{\text {th }}$ dose of NPK $(i=1,2, \ldots, 4)$;

$\mathrm{M}_{\mathrm{i}}=$ effect of the $\mathrm{j}^{\text {th }}$ mixture $(\mathrm{j}=1,2)$;

$\mathrm{AM}_{\mathrm{ij}}=$ effect of the interaction of the $\mathrm{i}^{\text {th }}$ dose of NPK and the $\mathrm{j}^{\text {th }}$ mixture;

$\beta_{\mathrm{k}}=$ effect of the $\mathrm{k}^{\text {th }}$ block;

$\varepsilon_{(\mathrm{ijk})}=$ experimental error associated to the plot;

$\tau_{1}=$ effect of the $1^{\text {th }}$ time $(1=1,2)$;

$\varepsilon_{(\mathrm{kl})}=$ experimental error associated to the subplot; $\mathrm{A} \tau_{\mathrm{il}}=$ effect of the interaction of the $\mathrm{i}^{\text {th }}$ dose of NPK and the $\mathrm{l}^{\text {th }}$ time;

$\mathrm{M} \tau_{\mathrm{j} 1}=$ effect of the interaction of the $\mathrm{j}^{\text {th }}$ mixture and the $1^{\text {th }}$ time;

$\mathrm{AM} \tau_{\mathrm{ijl}}=$ effect of the interaction of the $\mathrm{i}^{\text {th }}$ dose of NPK and the $\mathrm{j}^{\text {th }}$ mixture and the $\mathrm{l}^{\text {th }}$ time;

$\varepsilon_{(\mathrm{ijkl})}=$ experimental error associated to the subplot.

\section{RESULTS AND DISCUSSION}

It was observed that only the NPK doses influenced the number of leaves formed and the addition of the fertilizer mixture did not make any difference. There was also no interaction between the NPK doses used and the mixture of fertilizers added to the substrate.

It was verified that the increase in the number of leaves was proportional to the increase in the doses of NPK applied or, in other words, as the NPK concentration was increased, a linear increase also occurred in the number of leaves formed. Therefore, as can be seen on Figure 1, the highest number of leaves (18.34) was reached when 1.5 $\mathrm{g} \mathrm{L}^{-1}$ of NPK was applied.

These results are in accordance with the indications of Hewitt (1997), who reports that cacti and succulents are plants that need regular application of fertilizers during the growth phase, with a balanced quantity of minerals.

The ornamental value of this species is attributed to the quantity of leaves per plant. Therefore, the higher the number of leaves, the higher its market value would be. Consequently, it can be inferred that the supply of mineral nutrients is a necessity in the commercial cultivation of this species.

The doses of NPK applied were also effective on the plant height. The application of the highest dose of NPK $(1.5 \mathrm{~g}$ $\mathrm{L}^{-1}$ ) resulted in $18.73-\mathrm{cm}$-tall plants, being $2.98 \mathrm{~cm}$ taller compared to those that did not receive any fertilizer (Figure 2).

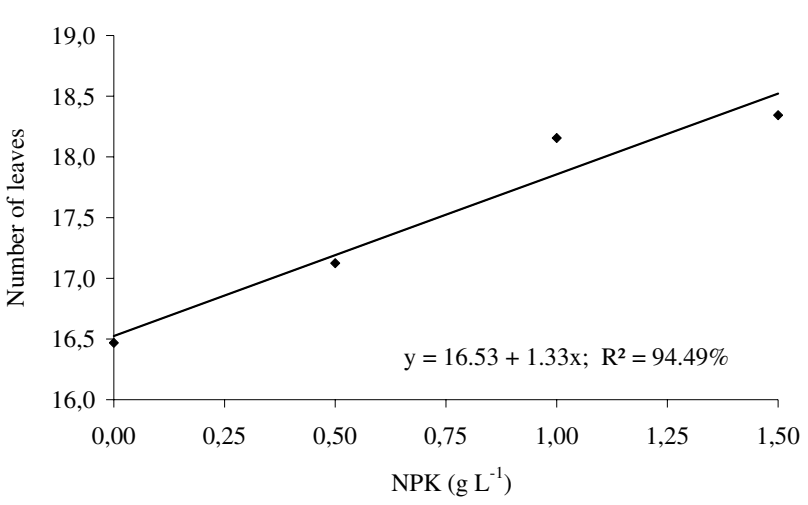

Figure 1 - Number of leaves formed in Kalanchoe luciae plants cultivated in substrate with different doses of NPK (10:10:10).

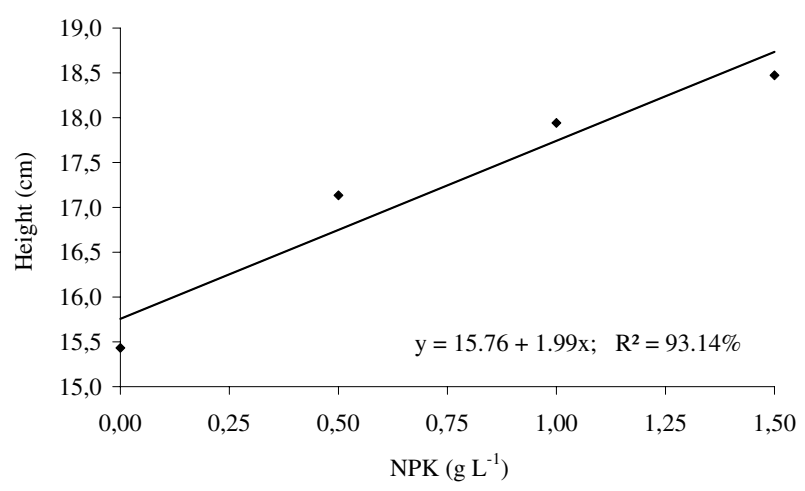

Figure 2 - Height $(\mathrm{cm})$ of Kalanchoe luciae plants, in substrate with different doses of NPK (10:10:10).

There was a linear response in the height of the plants formed, in the same way as occurred with the number of leaves, due to the increase in the NPK doses.

The use of mixture of fertilizers did not interfere in the plant height (Figure 3) and the interactions between NPK and the mixture applied also did not promote differences in the plant height.

For $K$. luciae, it can be observed that the plants that reached the greatest height also presented the highest number of leaves. The plant height in $K$. luciae is a variable that cannot be taken in consideration by itself because its ornamental aspect also depends on the number of leaves and the plant diameter. Even though, there is no commercial standard established for this species, some producers, based on the knowledge of its behavior in the natural habitats, empirically suggest that more compact plants have greater commercial value, compared to those that 
present excessive shoot growth. Therefore, plants of $K$. luciae with higher number of leaves and bigger diameter are commercially more valuable than those plants that present excessive shoot growth (long internodes and petioles), even when they present a considerable diameter and number of leaves. Mota et al. (2008) increased tansagem leaves number using phosphorus fertilization.
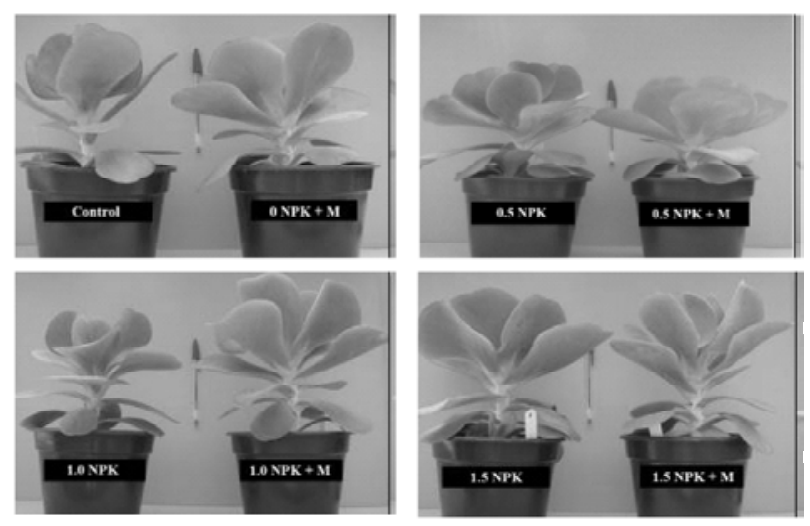

Figure 3 - Visual aspect of Kalanchoe luciae plant heights, cultivated on standard substrate added with different doses of NPK.

The applications of NPK and the use of the fertilizer mixture did not influence the plant diameter. As a result, no interaction between the applications of NPK and the addition of the fertilizer mixture was detected.

According to Larcher (2000) and Olmos (1978), succulent plants excessively fertilized with nitrogen can become etiolated, which accounts for the greater development in height than in diameter observed in $K$. luciae.

The diameter of the leaves was also analyzed, by measuring the fifth expanded leaf. The fifth pair of Kalanchoe luciae leaves is the most noticeable in the plant structure as a whole. The characteristic that differentiates the fifth pair of leaves from the other remaining pairs is the diameter, which is bigger in the former. Therefore, they give a more appealing visual aspect to the plant.

Upon evaluating the fifth leaf, it was observed that the development was neither influenced by the doses of NPK nor by the interaction between these doses and the fertilizer mixture. Only the fertilizer mixture by itself influenced the development of the fifth leaf. It was observed that plants that received the fertilizer mixture presented the fifth leaf with bigger diameter, compared to the plants that did not receive the mixture on the substrate (Table 1).
Table 1 - Average diameter of the fifth leaf of Kalanchoe luciae plants cultivated with different fertilizers applied to the culture substrate.

\begin{tabular}{cc}
\hline Fertilizer mixture & Diameter $(\mathrm{cm})^{1}$ \\
\hline Without mixture & $7.11 \mathrm{~b}$ \\
With mixture & $8.01 \mathrm{a}$
\end{tabular}

${ }^{1}$ Means followed by the same letter did not differ at $5 \%$ probability by Tukey test.

From the results presented herein it can be observed that the addition of the fertilizer mixture interfered only in the diameter of the fifth leaf. Even presenting differences, the value added was very low $(0.90 \mathrm{~cm})$ when compared to the treatment without the use of the mixture. This way, its use would generate an unnecessary expense for the producer who could obtain good results in the development of $K$. luciae using only NPK as increment in the fertilization.

San Marcos Growers (2006) characterize K. luciae as a species that presents leaves with reddish margins especially when cultivated during periods of cooler temperatures. The plants from this experiment did not present reddish color probably because they were cultivated in the summer. Another induction factor for the coloration in K. luciae is the light. Plants cultivated under higher light intensity were redder. Plants from this experiment were kept in a greenhouse under $50 \%$ shade, which justifies the absence of this reddish color and the presence of green leaves only.

From the analysis of nutrient accumulation, it is possible to infer on the absorption of nutrients furnished to the cultivated plantlets. In general, it can be observed from data on Table 2, that plants that did not receive the fertilizer mixture in the substrate presented higher accumulation of macro and micronutrients, with exception of $\mathrm{Ca}$, which had higher accumulation in plants added with the mixture, as described by Larcher (2000), where the value of Ca was higher than $\mathrm{K}$ in the species of the Crassulaceae family.

It is also observed that the macronutrients accumulated by the plants presented different profiles in the treatments that did receive fertilizer mixture when compared to the plants that did not receive the mixture.

The accumulation of Ca increased as the doses of NPK increased, therefore, a lower absorption of $\mathrm{K}$ occurred due to the competitive inhibition caused by $\mathrm{Ca}$, an effect already reported by Malavolta (1980). The accumulation of $\mathrm{Mg}$ and B also presented the same increasing tendency with higher dose of NPK. This same tendency was observed regarding the leaf concentrations, where the contents of accumulated $\mathrm{Mn}, \mathrm{Zn}$, and Fe tended to be higher in plants that did not receive the mixture. 
Table 2 - Accumulation of macronutrients and micronutrients in leaves of $K$. luciae plants cultivated under different applications of fertilizer in the substrate.

\begin{tabular}{lccccc}
\hline \multicolumn{1}{c}{ Treatment } & \multicolumn{5}{c}{ Macronutrients (g/plant) } \\
\cline { 2 - 6 } & $\mathrm{N}$ & $\mathrm{P}$ & $\mathrm{K}$ & $\mathrm{Ca}$ & $\mathrm{Mg}$ \\
\hline $0 \mathrm{NPK}$ & 1.00 & 0.08 & 2.23 & 1.80 & 0.41 \\
$0 \mathrm{NPK}+\mathrm{M}$ & 0.56 & 0.05 & 1.56 & 3.05 & 0.30 \\
$0.5 \mathrm{NPK}$ & 1.33 & 0.10 & 2.26 & 2.73 & 0.62 \\
$0.5 \mathrm{NPK}+\mathrm{M}$ & 0.71 & 0.06 & 1.60 & 3.09 & 0.35 \\
$1.0 \mathrm{NPK}$ & 1.60 & 0.13 & 1.74 & 2.40 & 0.58 \\
$1.0 \mathrm{NPK}+\mathrm{M}$ & 1.32 & 0.11 & 1.88 & 3.59 & 0.60 \\
$1.5 \mathrm{NPK}$ & 1.34 & 0.09 & 2.35 & 4.13 & 0.64 \\
$1.5 \mathrm{NPK}+\mathrm{M}$ & 1.45 & 0.11 & 2.21 & 4.25 & 0.61 \\
\hline \multicolumn{1}{c}{ Treatment } & & \multicolumn{3}{c}{ Micronutrients (mg/plant) } & \\
& $\mathrm{B}$ & $\mathrm{Cu}$ & $\mathrm{Fe}$ & $\mathrm{Mn}$ & $\mathrm{Zn}$ \\
\hline $0 \mathrm{NPK}$ & 0.84 & 0.50 & 26.54 & 4.14 & 1.41 \\
$0 \mathrm{NPK}+\mathrm{M}$ & 0.82 & 0.35 & 13.17 & 2.14 & 0.95 \\
$0.5 \mathrm{NPK}$ & 1.12 & 0.79 & 27.59 & 6.34 & 2.46 \\
$0.5 \mathrm{NPK}+\mathrm{M}$ & 1.32 & 0.56 & 14.39 & 3.24 & 1.51 \\
$1.0 \mathrm{NPK}$ & 1.33 & 0.51 & 23.43 & 5.52 & 2.68 \\
$1.0 \mathrm{NPK}+\mathrm{M}$ & 1.45 & 0.60 & 17.27 & 5.53 & 2.49 \\
$1.5 \mathrm{NPK}$ & 1.80 & 0.84 & 27.34 & 5.52 & 2.09 \\
$1.5 \mathrm{NPK}+\mathrm{M}$ & 1.78 & 0.73 & 14.82 & 3.82 & 1.92 \\
\hline
\end{tabular}

\section{CONCLUSIONS}

K. luciae plants presented greater development when $1.5 \mathrm{~g}$ of NPK $(10: 10: 10)$ was added to the substrate.

The use of fertilizer mixture $(5 \mathrm{~g}$ bone flour, $5 \mathrm{~g}$ dolomite limestone, and $50 \mathrm{~g}$ ground charcoal) did not interfere in $K$. luciae development.

Despite their health aspect, $K$. luciae plants cultivated on substrate (1 soil:1vermiculie: 1 sand) did not reach the commercial standard due to the excessive shoot growth, in addition to the absence of the reddish color on the leaf borders.

\section{REFERENCES}

ALMEIDA, E.F.A.; LUZ, P.B.; LESSA, M.A.L.; PAIVA, P.D.O.; ALBUQUERQUE, C.J.B.; OLIVEIRA, M.V.C. Diferentes substratos e ambientes para enraizamento de mini-ixora (Ixora coccinea Compacta). Revista Ciência e Agrotecnologia, Lavras, v.32, n.5, p.14491453, 2008.
BELL, S. A. Growing cacti and other succulents in the conservatory and indoors. United Kingdom: GMC, 2001.

HEWITT, T. The complete book of cacti \& succulents. London: Dorling Kindersley, 1997. 176 p.

FERREIRA, D. F. Análises estatísticas por meio do SISVAR para Windows versão 4.0. In: REUNIÃO ANUAL DA REGIÃO BRASILEIRA DA SOCIEDADE INTERNACIONAL DE BIOMETRIA, 45., 2000, São Carlos, SP. Anais... São Carlos: UFSCar, 2000. p. 225258.

JUDD, W. S. et al. Plant systematics: a phylogenetic approach. Sunderlnd: Sinauer, 2002. 576 p.

LARCHER, W. Ecofisiologia vegetal. São Carlos: UFSCar, 2000. 
LESSA, M. A. et al. Efeito de diferentes substratos sobre a propagação e desenvolvimento de duas espécies de Crassulaceae. In: ENCONTRO NACIONAL SOBRE SUBSTRATOS PARA PLANTAS, 4., 2004, Viçosa, MG. Resumos... Viçosa: UFV, 2004. p. 371.

MALAVOLTA, E. Elementos de nutrição mineral de plantas. São Paulo: Agronômica Ceres, 1980. 253 p.

MOTA, J. H.; MELO, E.P. de; SOARES, T.S.; VIEIRA, M. do C. Crescimento da espécie medicinal tansagem (Plantago major L.) em função da adubação fosfatada e nitrogenada. Ciência e Agrotecnologia, Lavras, v. 32, n. 6, p. 1748-1753, 2008.
OLDFIELD, S. Cactus and succulent plants: status survey and conservation action plan. United Kingdom: South Western, 1997.

OLMOS, J. F. B. Los cactos e las outras plantas suculentas. Madrid: Floraprint, 1978.

SAN MARCOS GROWERS. Kalanchoe luciae. Available at: <http://www.smgrowers.com/info/ kalanchoeluciae.asp>. Accessed on: 10 Jan. 2006.

SEIXAS, E. S. Emergência e desenvolvimento de plântulas de Cactaceae em diferentes substratos com e sem adubação. 2001. 74 p. Thesis (Master in AgronomyPlant Production) - Universidade Estadual Paulista, Jaboticabal, 2001. 